\title{
Reclassification of Bacillus axarquiensis Ruiz-García et al. 2005 and Bacillus malacitensis Ruiz-García et al. 2005 as later heterotypic synonyms of Bacillus mojavensis Roberts et al. 1994
}

Correspondence

Fwu-Ling Lee fll@firdi.org.tw

\author{
Li-Ting Wang, ${ }^{1}$ Fwu-Ling Lee, ${ }^{1}$ Chun-Ju Tai, ${ }^{1}$ Akira Yokota ${ }^{2}$ \\ and Hsiao-Ping Kuo ${ }^{1}$
}

\author{
${ }^{1}$ Bioresource Collection and Research Center, Food Industry Research and Development \\ Institute, PO Box 246, Hsinchu 30099, Taiwan \\ ${ }^{2}$ Institute of Molecular and Cellular Biosciences, The University of Tokyo, Yayoi 1-1-1, \\ Bunkyo-Ku, Tokyo 113-0032, Japan
}

\begin{abstract}
The Bacillus subtilis group encompasses the taxa Bacillus subtilis subsp. subtilis, B. licheniformis, B. amyloliquefaciens, B. atrophaeus, B. mojavensis, B. vallismortis, B. subtilis subsp. spizizenii, $B$. sonorensis, B. velezensis, B. axarquiensis and B. malacitensis. In this study, the taxonomic relatedness between the species $B$. axarquiensis, $B$. malacitensis and $B$. mojavensis was investigated. Sequence analysis of the 16S rRNA gene and the gene for DNA gyrase subunit B $(g y r B)$ confirmed the very high similarities between these three type strains and a reference strain of $B$. mojavensis ( $>99$ and $>97 \%$, respectively). DNA-DNA hybridization experiments revealed high relatedness values between the type strains of $B$. axarquiensis, $B$. malacitensis and $B$. mojavensis and between these strains and a reference strain of B. mojavensis (83-98\%). Based on these molecular taxonomic data and the lack of phenotypic distinctive characteristics, Bacillus axarquiensis and Bacillus malacitensis should be reclassified as later heterotypic synonyms of Bacillus mojavensis.
\end{abstract}

The species Bacillus subtilis (subsp. subtilis and subsp. spizizenii) (Smith et al., 1964; Nakamura et al., 1999), B. licheniformis (Skerman et al., 1980), B. amyloliquefaciens (Priest et al., 1987), B. atrophaeus (Nakamura, 1989), B. mojavensis (Roberts et al., 1994), B. vallismortis (Roberts et al., 1996), B. sonorensis (Palmisano et al., 2001), B. velezensis (Ruiz-García et al., 2005a), B. axarquiensis and B. malacitensis (Ruiz-García et al., 2005b), Gram-positive, rod-shaped, endospore-forming, aerobic and fermentative bacteria, are difficult to distinguish from each other by phenotypic characteristics alone, but can be differentiated from one another reliably by using DNA-DNA hybridization.

The GenBank/EMBL/DDBJ accession numbers for the 16S rRNA gene sequences of $B$. axarquiensis strains $\mathrm{CIP} 108772^{\top}$ and LMG $22476^{\top}$ and B. malacitensis strains CECT $5687^{\top}$ and LMG $22477^{\top}$ are D0993670-D0993673, respectively, and the accession numbers of the gyrB gene sequences of these four strains are D0903177D0903180, respectively.

Maximum-likelihood and maximum-parsimony trees based on $16 \mathrm{~S}$ rRNA and gyrB gene sequences and details of fatty acid profiles and differential phenotypic characteristics of the studied strains are available with the online version of this paper.
In the present study, we provide evidence, on the basis of sequence similarities of the $16 \mathrm{~S}$ rRNA and gyrB genes and DNA-DNA hybridization data, that the type strains of $B$. axarquiensis and $B$. malacitensis are very closely related to the type strain of $B$. mojavensis, suggesting that the three species represent the same species.

The bacterial strains used in this study were cultivated in nutrient agar or broth (Difco) and incubated aerobically at $30^{\circ} \mathrm{C}$. Genomic DNA was isolated and purified using the Qiagen Blood \& Cell Culture DNA kit. The complete sequence of a $1.5 \mathrm{~kb} 16 \mathrm{~S}$ rRNA gene fragment was determined using the MicroSeq Full Gene 16S rDNA bacterial identification kit (Applied Biosystems). Sequencing was performed using an ABI 3730 DNA sequencer (Applied Biosystems and Hitachi). Sequence assembly was performed using the ABI PRISM DNA Sequencing Analysis software (PE Applied Biosystems). Sequence similarity was calculated using the programs of the Wisconsin package version 10.1 (Accelrys Inc.). The sequences obtained in this study and from GenBank were aligned using the CLUSTAL_X program, version 1.8 (Thompson et al., 1997), and phylogenetic analysis was performed using the PHYLIP computer program package 
(Felsenstein, 2002). Phylogenetic trees were constructed using the neighbour-joining (Saitou \& Nei, 1987), maximum-parsimony (Fitch, 1971) and maximumlikelihood (Felsenstein, 1981) methods. Bootstrap analysis was made with 1000 replicates except in maximumlikelihood, where only 100 replicates were generated. Tree figures were drawn by TreeView software (Page, 1996).

Sequences of highly conserved housekeeping or other protein-encoding genes provide higher resolution than $16 \mathrm{~S}$ rRNA gene sequences and may supplant DNA-DNA reassociation or $16 \mathrm{~S} \mathrm{rRNA}$ gene sequence data at the species level for taxonomic analysis (Stackebrandt et al., 2002; Zeigler, 2003). The partial sequence for the gene encoding the subunit B protein of DNA gyrase $(g y r B)$ was included in the phylogenetic analysis for comparative purposes. An approximately $1.2 \mathrm{~kb}$ fragment of the gyrB gene was amplified by PCR and sequenced using a set of primers described by Yamamoto \& Harayama (1995). Using the method described above, the gyrB gene sequences were also aligned and phylogenetic trees were constructed. Phylogenetic analysis by the neighbour-joining (Fig. 1), maximum-parsimony and maximum-likelihood methods (see Supplementary Figs S1 and S2 available in IJSEM Online) produced similar trees with the exception of minor differences in the tree topology of the basal branches.

The 16S rRNA gene sequences (positions 35-1431; Escherichia coli K-12 numbering) of B. axarquiensis strains LMG $22476^{\mathrm{T}}$ and CIP $108772^{\mathrm{T}}$ and B. malacitensis strains LMG $22477^{\mathrm{T}}$ and CECT $5687^{\mathrm{T}}$ shared $99.9 \%$ similarity with each other and shared $99.9 \%$ similarity with sequences of $B$. mojavensis strains BCRC $17124^{\mathrm{T}}$ and BCRC 17531 (Fig. 1). Sequences of the $B$. axarquiensis and $B$. malacitensis type strains shared 99.6 and $99.5 \%$ similarity, respectively, with those of B. subtilis subsp. subtilis BCRC $10255^{\mathrm{T}}$ and B. amyloliquefaciens BCRC $11601^{\mathrm{T}}$. The $16 \mathrm{~S}$ rRNA gene sequences (positions 35-1431) of B. axarquiensis LMG $22476^{\mathrm{T}}$ and CIP $108772^{\mathrm{T}}$ and B. axarquiensis CR-119 ${ }^{\mathrm{T}}$ (GenBank accession no. AY603657) shared 99.9, 99.9 and $99.5 \%$ similarity, respectively, with that of $B$. mojavensis BCRC $17124^{\mathrm{T}}$. In contrast, the similarity between B. axarquiensis CR-119 $9^{\mathrm{T}}$ and $B$. mojavensis reported by RuizGarcía et al. (2005b) was noticeably lower, at $97.4 \%$. The gyrB gene sequences (positions 316-1480; E. coli K-12 numbering) for $B$. axarquiensis LMG $22476^{\mathrm{T}}$ and CIP $108772^{\mathrm{T}}$ and B. malacitensis LMG $22477^{\mathrm{T}}$ and CECT $5687^{\mathrm{T}}$ showed high similarities $(>97 \%)$ with the investigated $B$. mojavensis strains and significantly lower similarities (ranging from 80 to $90 \%$ ) with their nearest neighbour (Fig. 1b). The similarities of the $16 \mathrm{~S}$ rRNA and gyrB gene sequences indicate that $B$. axarquiensis, $B$. malacitensis and B. mojavensis cannot be differentiated and may represent the same species.

The $\mathrm{G}+\mathrm{C}$ content was determined using reversed-phase HPLC according to Tamaoka \& Komagata (1984) with slight modifications. The nucleoside mixture was separated using a Cosmosil $5 \mathrm{C}_{18}$ column (Waters, $4.0 \times 150 \mathrm{~mm}$;
Nacalai Tesque) in a mobile phase composed of $0.2 \mathrm{M}$ $\left(\mathrm{NH}_{4}\right) \mathrm{H}_{2} \mathrm{PO}_{4}$ /acetonitrile $(20: 1, \mathrm{v} / \mathrm{v})$ at a flow rate of $1 \mathrm{ml} \mathrm{min}{ }^{-1}$ at room temperature. DNA relatedness values between B. axarquiensis LMG $22476^{\mathrm{T}}$ and CIP $108772^{\mathrm{T}}, B$. malacitensis LMG $22477^{\mathrm{T}}$ and CECT $5687^{\mathrm{T}}$, B. mojavensis strains BCRC $17124^{\mathrm{T}}$ and BCRC 17531, B. subtilis subsp. subtilis BCRC $10255^{\mathrm{T}}$ and B. amyloliquefaciens BCRC $11601^{\mathrm{T}}$ were determined using the fluorometric hybridization method in microdilution wells as described previously (Ezaki et al., 1989; Goris et al., 1998; Chern et al., 2004). The hybridization temperature was $42{ }^{\circ} \mathrm{C}$. DNA G $+\mathrm{C}$ contents of B. axarquiensis (LMG $22476^{\mathrm{T}}$ and CIP $108772^{\mathrm{T}}$ ), B. malacitensis (LMG $22477^{\mathrm{T}}$ and CECT $5687^{\mathrm{T}}$ ) and B. mojavensis strains BCRC $17124^{\mathrm{T}}$ and BCRC 17531 were respectively 43, 44, 44 and $44 \mathrm{~mol} \%$. These values were close to the value of $43 \mathrm{~mol} \%$ determined for the type strain of $B$. mojavensis by Roberts et al. (1994). The relatedness values of genomic DNA of the strains tested are showed in the Table $1 . B$. axarquiensis LMG $22476^{\mathrm{T}}$ and CIP $108772^{\mathrm{T}}$, B. malacitensis LMG $22477^{\mathrm{T}}$ and CECT $5687^{\mathrm{T}}$ and B. mojavensis BCRC $17124^{\mathrm{T}}$ and BCRC 17531 showed high DNA-DNA relatedness values, in the range $83-98 \%$, indicating clearly that these taxa belong to the same genospecies. These strains showed less than $40 \%$ relatedness with $B$. subtilis subsp. subtilis BCRC $10255^{\mathrm{T}}$, B. vallismortis BCRC $17183^{\mathrm{T}}$ and $B$. amyloliquefaciens BCRC $11601^{\mathrm{T}}$. The results contradict those obtained by Ruiz-García et al. (2005b), who reported a low hybridization value of less than $47 \%$ between the type strains of these taxa.

Cellular fatty acid composition was determined using the Sherlock Microbial Identification System (MIDI Inc.). Extracts of methylated fatty acids were prepared according to the protocol provided by the manufacturer and analysed with an Agilent $6890 \mathrm{~N}$ gas chromatograph equipped with a flame-ionization detector and 7683 Automatic Liquid Sampler (Agilent). Identification of peaks was made by comparing the results with the built-in TSBA 50 database (MIDI Inc.). The fatty acid compositions of phylogenetically related species are listed in Supplementary Table S1 (available in IJSEM Online). In strains of $B$. axarquiensis, $B$. malacitensis and B. mojavensis, iso- and anteiso-fatty acids with 15 to 17 carbons predominated. Their fatty acids profiles showed high similarity, and could not be used to differentiate the strains from one another or from B. subtilis. The results differed from those obtained by Ruiz-García et al. (2005b), who reported a significant quantity (11.5\%) of 16:0 fatty acid in B. axarquiensis CR- $119^{\mathrm{T}}$ and no unsaturated fatty acids in B. axarquiensis CR-119 $9^{\mathrm{T}}$ or $B$. malacitensis $\mathrm{CR}-95^{\mathrm{T}}$.

Additional biochemical tests were performed using the API CH50 and 20E kits (bioMérieux) according to the manufacturer's instructions. Supplementary Table S2 shows differential biochemical features between the tested Bacillus strains. Very few of these characteristics could be used to differentiate $B$. axarquiensis and $B$. malacitensis from one another or from the other species. Only a negative oxidase 
(a)

65 B. subtilis BCRC 14714 (EF423593)

B. subtilis BCRC 14718 (EF423597)

B. subtilis BCRC 17443 (EF423603)

B. subtilis BCRC 17442 (EF423602)

B. subtilis BCRC 17441 (EF423601)

B subtilis BCRC 17437 (EF42360)

B. subtilis BCRC 14710 (EF423595)

B.

B. subtilis subsp. subtilis BCRC $10255^{\top}$ (EF423592)

B. sublits subsp. subins BCRC 10255

B. Subths BCRC 14717 (EF423500)

B. subuhs BCRC 14715 (EF423594)

B. subtilis BCRC 17435 (EF423598) B. axarqujensis CR-119' (AY603657) B. axarquiensis CIP $108772^{\top}$ (DQ993670)

60. axarquiensis LMG 22476 ${ }^{\top}$ (DQ993671)

B malacitensis LMG 22477 (DQ993673)

59 B malacitonsis CECT $5687^{\top}$ (DQ993672)

T. B. mojavensis BCRC 17124 (EF433405)

B. mojavensis BCRC 17531 (

B. mavensis BCRC 17531 (DQ993678

B. malacitonsis CR-95T (AY003650)

- B. velezensis BCRC 17467 (EF433407)

B. amyloliquefoci

B. amylohquefaciens BCRC $11601^{\top}$ (EF433406)

B. amyloliquefaciens BCRC 14711 (EF423607)

B. amyloliquefaciens BCRC 11266 (EF423605)

B. amyloliquefaciens BCRC 17038 (DQ993675)

B. amylaliquefaciens BCRC 12815 (EF423604)

B. amyloliquefaciens BCRC 14710 (EF423606)

B. atrophaeus BCRC 17123 (EF433409)

94 B. licheniformis BCRC 11702 ${ }^{\top}$ (EF433410)

$100 \quad$ B. sonorensis BCRC $17416^{\top}$ (EF433411)

4 B. licheniformis BCRC 12826 (EF423608)

91 B. licheniformis BCRC 15413 (DQ993676)

0.01 (b)

55. Bubtilis BCRC 17435 (DQ309317)

B. subtilis BCRC 17437 (DQ309319)

B. subtilis BCRC 17443 (DQ309322)

87 B. subtilis BCRC 17442 (DQ309321)

B. subtilis BCRC 14716 (DQ309314)

B. subtilis BCRC 17436 (DQ309318)

B. subtilis BCRC 14717 (DQ309315)

B. subtilis BCRC 14718 (DQ309316)

B. subtilis BCRC 14715 (DQ309313)

100 . subtils BCRC 10058 (DQ300300)

100 B. subilis BCRC 10058 (DQ309306)

B. subitis subsp subtilis BCRC 102

$5^{\top}(\mathrm{DQ} 309293)$

B. subtilis subsp spizizenii BCRC $17366^{\top}$ (DQ309299)

93 B. subtilis subsp. spizizenii BCRC 10447 (DQ309301)

- B. vallismortis BCRC $17183^{\top}$ (DQ309298)

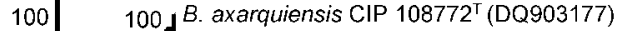

B. axarquiensis LMG $22476^{\top}(\mathrm{DQ903178)}$

8. mojavensis BCRC 17531 (DQ300303)

B. mavest

4 B. malactensis LMG 22477 (DQ903180)

100 B. malacitensis CECT $5687^{\top}$ (DQ903179)
B. mojavensis BCRC $17124^{\top}$ (DQ309297)

B. amyloliquefaciens BCRC 12815 (DQ309308)

B. amyloliquefaciens BCRC 14710 (DQ309310)

B. amyloliquefaciens BCRC 17038 (DQ309305)

97 B. amyloliquefaciens BCRC 11266 (DQ309307)

B. amyloliquefaciens BCRC 11601' (DQ309294)

B. velezensis BCRC $17467^{\top}$ (DQ903176)

B. atrophaeus BCRC 17123' (DQ309296)

atrophaeus BCRC 17530 (DQ309302)

$100{ }^{B}$ B. licheniformis BCRC $11702^{\top}$ (DQ309295)

B. licheniformis BCRC 14353 (DQ309324)

- B. licheniformis BCRC 12826 (DQ309323)

90 - B licheniformis BCRC 15413 (DQ309325)

$100 \mathrm{H}^{B}$. sonorensis BCRC $17416^{\top}$ (DQ309300)

B. sonorensis BCRC 17532 (DQ309304)

Fig. 1. Neighbour-joining trees based on $16 \mathrm{~S}$ rRNA (a) and gyrB (b) gene sequences of Bacillus strains. Genetic distances were computed by Kimura's two-parameter model. Escherichia coli K-12 was used as an outgroup. Only bootstrap percentages above $50 \%$ are shown. Bars, 0.01 (a) and 0.1 (b) substitutions per nucleotide position. 
Table 1. DNA-DNA relatedness values between Bacillus strains

ATCC, American Type Culture Collection (Manassas, VA, USA); BCRC, Bioresource Collection and Research Center at Food Industry Research and Development Institute (FIRDI) (Hsinchu, Taiwan); CECT, Colección Española de Cultivos Tipo, Universidad de Valencia (Valencia, Spain); CIP, Collection Bactérienne de l'Institut Pasteur (Paris, France); DSM, Deutsche Sammlung von Mikroorganismen und Zellkulturen GmbH (Braunschweig, Germany); LMG, Culture Collection of the Laboratorium voor Microbiologie Gent, Universiteit Gent (Gent, Belgium).

\begin{tabular}{|c|c|c|c|}
\hline \multirow[t]{2}{*}{ Source of unlabelled DNA } & \multicolumn{3}{|c|}{ Relatedness (\%) to labelled DNA from: } \\
\hline & $\begin{array}{l}\text { B. axarquiensis } \\
\text { LMG } 22476^{T}\end{array}$ & 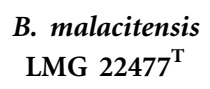 & $\begin{array}{l}\text { B. mojavensis } \\
\text { BCRC } 17124^{\mathrm{T}}\end{array}$ \\
\hline B. axarquiensis $\mathrm{LMG} 22476^{\mathrm{T}}\left(=\mathrm{BCRC} 17501^{\mathrm{T}}\right)$ & 100 & 85 & 98 \\
\hline B. axarquiensis CIP $108772^{\mathrm{T}}\left(=\mathrm{BCRC} 17653^{\mathrm{T}}\right)$ & 99 & 90 & 97 \\
\hline B. malacitensis LMG $22477^{\mathrm{T}}\left(=\mathrm{BCRC} 17502^{\mathrm{T}}\right)$ & 87 & 100 & 86 \\
\hline B. malacitensis CECT $5687^{\mathrm{T}}\left(=\mathrm{BCRC} 17654^{\mathrm{T}}\right)$ & 84 & 99 & 83 \\
\hline B. mojavensis BCRC $17124^{\mathrm{T}}\left(=\mathrm{DSM} 9205^{\mathrm{T}}\right)$ & 97 & 84 & 100 \\
\hline B. mojavensis BCRC 17531 (=DSM 9206) & 84 & 83 & 83 \\
\hline B. subtilis subsp. subtilis BCRC $10255^{\mathrm{T}}\left(=\right.$ ATCC $\left.6051^{\mathrm{T}}\right)$ & 31 & 39 & 31 \\
\hline B. vallismortis $\mathrm{BCRC} 17183^{\mathrm{T}}\left(=\mathrm{DSM} 11031^{\mathrm{T}}\right)$ & 35 & 37 & 35 \\
\hline B. amyloliquefaciens BCRC $11601^{\mathrm{T}}\left(=\right.$ ATCC $\left.23350^{\mathrm{T}}\right)$ & 15 & 17 & 15 \\
\hline
\end{tabular}

test and positive reactions for acid production from gentiobiose and inulin differentiated $B$. axarquiensis from $B$. malacitensis and B. mojavensis. Additionally, B. axarquiensis LMG $22476^{\mathrm{T}}$ and CIP $108772^{\mathrm{T}}$ are both negative for arginine dihydrolase, lysine decarboxylase and ornithine decarboxylase activities (not shown in Supplementary Table S2), which differed from the results obtained by Ruiz-García et al. (2005b).

Although RAPD analysis with primers OPA3 and OPL12 could be used to distinguish $B$. axarquiensis and B. malacitensis from one another and from B. mojavensis (RuizGarcía et al., 2005b), genetic heterogeneity in the same species has also been reported by some authors (Tynkkynen et al., 1999; Matarante et al., 2004; Naser et al., 2006).

Previous data reported by Ruiz-García et al. (2005b) gave DNA-DNA relatedness values for $B$. axarquiensis and $B$. malacitensis strains with strains of other closely related species that were lower than $46.9 \%$, which is much lower than the values (83-99\%) determined in our study. Our results show that the strains submitted to the culture collections are pure, and our DNA-DNA hybridization experiments clearly identify the $B$. axarquiensis and B. malacitensis type strains, as deposited in the culture collections, as B. mojavensis. The DNA-DNA hybridization experiments confirmed the results of our other investigation methods (16S rRNA and gyrB gene sequencing) used to differentiate between the species. In addition, these methods could clearly distinguish between type or reference strains of other closely related species. Our investigation shows clearly that the $B$. axarquiensis and B. malacitensis type strains can not be distinguished from the B. mojavensis type strain or another B. mojavensis reference strain at the species level. The data from the present study show that no significant phenotypic or genotypic differences exist to justify the separation of the type strains of $B$. axarquiensis and B. malacitensis and that of B. mojavensis. Consequently, it is proposed that Bacillus axarquiensis Ruiz-García et al. 2005 and Bacillus malacitensis Ruiz-García et al. 2005 should be considered as later heterotypic synonyms of Bacillus mojavensis Roberts et al. 1994.

\section{Emended description of Bacillus mojavensis Roberts et al. 1994}

The description is the same as that given by Roberts et al. (1994) except for the following traits. Oxidase, citrate utilization and nitrite reduction are variable. Does not hydrolyse L-rhamnose or D-galactose. Acid production from D-xylose, inositol, inulin, D-raffinose, gentiobiose, amygdalin and methyl $\alpha$-D-glucoside is strain-dependent. Major fatty acids are 15:0 anteiso, 15:0 iso, 17:0 iso and 17:0 anteiso. The DNA $\mathrm{G}+\mathrm{C}$ content ranges from 43 to $44 \mathrm{~mol} \%$. Known habitats are desert soils and brackish sediments. Additional chemotaxonomic data and results of biochemical tests are given in Supplementary Tables S1 and S2.

The type strain is strain RO-H-1 ${ }^{\mathrm{T}}\left(=\mathrm{NRRL} \mathrm{B}-14698^{\mathrm{T}}=\right.$ DSM $\quad 9205^{\mathrm{T}}=\mathrm{LMG} \quad 17797^{\mathrm{T}}=\mathrm{CIP} \quad 104095^{\mathrm{T}}=$ ATCC $51516^{\mathrm{T}}=$ BCRC $17124^{\mathrm{T}}=\operatorname{NBRC} 15718^{\mathrm{T}}$ ).

\section{Acknowledgements}

We thank T. Y. Liu, C. C. Liao and G. F. Yuan (Food Industry Research and Development Institute, Taiwan) for their encouragement. This research was supported by the Taiwanese Ministry of Economic Affairs (project no. 95-EC-17-A-17-R7-0525).

\section{References}

Chern, L. L., Stackebrandt, E., Lee, S. F., Lee, F. L., Chen, J. K. \& Fu, H. M. (2004). Chitinibacter tainanensis gen. nov., sp. nov., a 
chitin-degrading aerobe from soil in Taiwan. Int J Syst Evol Microbiol 54, 1387-1391.

Ezaki, T., Hashimoto, Y. \& Yabuuchi, E. (1989). Fluorometric deoxyribonucleic acid-deoxyribonucleic acid hybridization in microdilution wells as an alternative to membrane filter hybridization in which radioisotopes are used to determine genetic relatedness among bacterial strains. Int J Syst Bacteriol 39, 224-229.

Felsenstein, J. (1981). Evolutionary trees from DNA sequences: a maximum likelihood approach. J Mol Evol 17, 368-376.

Felsenstein, J. (2002). PHYLIP (phylogeny inference package), version 3.6a. Distributed by the author. Department of Genome Sciences, University of Washington, Seattle, USA.

Fitch, W. M. (1971). Toward defining the course of evolution: minimum change for a specific tree topology. Syst Zool 20, 406-416.

Goris, J., Suzuki, K., De Vos, P., Nakase, T. \& Kersters, K. (1998). Evaluation of a microplate DNA-DNA hybridization method compared with the initial renaturation method. Can J Microbiol 44, 1148-1153.

Matarante, A., Baruzzi, F., Cocconcelli, P. S. \& Morea, M. (2004). Genotyping and toxigenic potential of Bacillus subtilis and Bacillus pumilus strains occurring in industrial and artisanal cured sausages. Appl Environ Microbiol 70, 5168-5176.

Nakamura, L. K. (1989). Taxonomic relationship of black-pigmented Bacillus subtilis strains and a proposal for Bacillus atrophaeus sp. nov. Int J Syst Bacteriol 39, 295-300.

Nakamura, L. K., Roberts, M. S. \& Cohan, F. M. (1999). Relationship of Bacillus subtilis clades associated with strains 168 and W23: a proposal for Bacillus subtilis subsp. subtilis subsp. nov. and Bacillus subtilis subsp. spizizenii subsp. nov. Int J Syst Bacteriol 49, 1211-1215.

Naser, S. M., Hagen, K. E., Vancanneyt, M., Cleenwerck, I., Swings, J. \& Tompkins, T. A. (2006). Lactobacillus suntoryeus Cachat and Priest 2005 is a later synonym of Lactobacillus helveticus (Orla-Jensen 1919) Bergey et al. 1925 (Approved Lists 1980). Int J Syst Evol Microbiol 56, 355-360.

Page, R. D. M. (1996). TreeView: an application to display phylogenetic trees on personal computers. Comput Appl Biosci 12, 357-358.

Palmisano, M. M., Nakamura, L. K., Duncan, K. E., Istock, C. A. \& Cohan, F. M. (2001). Bacillus sonorensis sp. nov., a close relative of Bacillus licheniformis, isolated from soil in the Sonoran Desert, Arizona. Int J Syst Evol Microbiol 51, 1671-1679.

Priest, F. G., Goodfellow, M., Shute, L. A. \& Berkeley, R. C. W. (1987). Bacillus amyloliquefaciens sp. nov., nom. rev. Int J Syst Bacteriol 37, 69-71.

Roberts, M. S., Nakamura, L. K. \& Cohan, F. M. (1994). Bacillus mojavensis sp. nov., distinguishable from Bacillus subtilis by sexual isolation, divergence in DNA sequence, and differences in fatty acid composition. Int J Syst Bacteriol 44, 256-264.

Roberts, M. S., Nakamura, L. K. \& Cohan, F. M. (1996). Bacillus vallismortis sp. nov., a close relative of Bacillus subtilis, isolated from soil in Death Valley, California. Int J Syst Bacteriol 46, 470-475.

Ruiz-García, C., Bejar, V., Martinez-Checa, F., Llamas, I. \& Quesada, E. (2005a). Bacillus velezensis sp. nov., a surfactantproducing bacterium isolated from the river Velez in Malaga, southern Spain. Int J Syst Evol Microbiol 55, 191-195.

Ruiz-García, C., Quesada, E., Martinez-Checa, F., Llamas, I., Urdaci, M. C. \& Bejar, V. (2005b). Bacillus axarquiensis sp. nov. and Bacillus malacitensis sp. nov., isolated from river-mouth sediments in southern Spain. Int J Syst Evol Microbiol 55, 1279-1285.

Saitou, N. \& Nei, M. (1987). The neighbor-joining method: a new method for reconstructing phylogenetic trees. Mol Biol Evol 4, 406-425.

Skerman, V. B. D., McGowan, V. \& Sneath, P. H. A. (editors) (1980). Approved lists of bacterial names. Int J Syst Bacteriol 30, 225-420.

Smith, N. R., Gibson, T., Gordon, R. E. \& Sneath, P. H. A. (1964). Type cultures and proposed neotype cultures of some species in the genus Bacillus. J Gen Microbiol 34, 269-272.

Stackebrandt, E., Frederiksen, W., Garrity, G. M., Grimont, P. A. D., Kämpfer, P., Maiden, M. C., Nesme, X., Rosselló-Mora, R., Swings, J. \& other authors (2002). Report of the ad hoc committee for the re-evaluation of the species definition in bacteriology. Int J Syst Evol Microbiol 52, 1043-1047.

Tamaoka, J. \& Komagata, K. (1984). Determination of DNA base composition by reversed-phase high-performance liquid chromatography. FEMS Microbiol Lett 25, 125-128.

Thompson, J. D., Gibson, T. J., Plewniak, F., Jeanmougin, F. \& Higgins, D. G. (1997). The CLUSTAL_X windows interface: flexible strategies for multiple sequence alignment aided by quality analysis tools. Nucleic Acids Res 25, 4876-4882.

Tynkkynen, S., Satokari, R., Saarela, M., Mattila-Sandholm, T. \& Saxelin, M. (1999). Comparison of ribotyping, randomly amplified polymorphic DNA analysis, and pulsed-field gel electrophoresis in typing of Lactobacillus rhamnosus and L. casei strains. Appl Environ Microbiol 65, 3908-3914.

Yamamoto, S. \& Harayama, S. (1995). PCR amplification and direct sequencing of $g y r B$ genes with universal primers and their application to the detection and taxonomic analysis of Pseudomonas putida strains. Appl Environ Microbiol 61, 1104-1109.

Zeigler, D. R. (2003). Gene sequences useful for predicting relatedness of whole genomes in bacteria. Int J Syst Evol Microbiol 53, 1893-1900. 